\title{
POLYGAMY: BETWEEN CONCEPT AND REALITY FOR WOMEN
}

\author{
JAMILAH \\ Dosen Luar Biasa fakultas Humaniora dan Budaya UIN Malang
}

\begin{abstract}
Abstrak
Konsepsi tentang perempuan adalah salah satu isu yang paling sering dibicarakan khususnya diantara berbagai konsepsi sosial yang ada. Salah satu isu yang berkaitan dengan perempuan yang sering dibahas adalah poligami yang menimbulkan berbagai respon yang berbeda dari berbagai pihak dalam menyikapi isu tersebut. Perdebatan panjang tentang praktek poligami di masyarakat berdasar pada legalitas poligami dan dampaknya terhadap perempuan. Praktek poligami juga menarik perhatian banyak kalangan terutama ketika terjadi pro dan kontra. Bagi kelompok yang berpihak pada praktek poligami selalu berusaha mengemas alasan klise untuk mendukung argumen mereka. Sebaliknya, bagi kelompok yang menyuarakan isu-isu gender dan perempuan terus membangun argumen yang berusaha membuktikan bahwa poligami berpeluang untuk memberikan dampak yang negatif bagi perempuan. Terlepas dari kedua kutub tersebut, poligami merupakan suatu isu yang terus mengabadi sebagai wacana yang bersifat polemis yang nampaknya tidak mudah untuk berujung pada suatu kesepakatan dalam tataran konsep dan realitas.
\end{abstract}

\section{A. Introduction}

Polygamy is an ancient practice found in the annals of history for a diverse spectrum of civilizations. For the Muslim world, this type of marriage is an important issue. It is crucial because of its impact on women, socially and psychologically, has stirred much debate by academics concerned with gender issues. Of all the issues canvassed in this paper, it is the one that has aroused the greatest depth of feeling among women in particular areas where woman has exclusively experienced it. It is considered as a complex issue which touches many aspects of life i.e emotional, moral, sexual, legal and religious aspects 
of marriage. The practice emerged over the centuries for many reasons. A study by G. P. Murdock in the early 1940s, for instance, revealed that many social communities were familiar with polygamy and the most common form was "polygyny", in which a man has more than one wife. ${ }^{1}$ His sample population included individuals from different ethnic, racial, cultural, and religious backgrounds. The result showed that only $19 \%$ of the sample practiced monogamy, while the rest practiced polygyny. Additionally, in Indonesian context, polygamy is a much older history in the archipelago. It was permitted according to a number of different customary legal system (adat) such as in Hindu Bali and among Chinese Indonesian. ${ }^{2}$ A study on women position in Bali by R. Van Eck in 1983 revealed that polygamy was commonly practiced in this island and was legitimized by Hindu religious teachings. ${ }^{3}$ Further, Koentjaraningrat in his study on Javanese culture also suggested that polygamy already existed in Javanese society where the wives were attributed to different statuses as well as different roles. ${ }^{4}$ Therefore, the discussion on the practice of polygamy is a broad cross-cultural as well as religious concept which need a wise response.

\footnotetext{
${ }^{1}$ Budi Radjab, Meninjau Poligami; Perspektif Antropologis Dan Keharusan Mengubahnya, Jurnal Perempuan 31, (2003) p. 70. Common usage refers to polygamy, a broader term meaning the practice of having more than one spouse. The term polygyny indicates the practice of marriage involving more than one wife simultaneously. However, the term polygamy is more familiar and is more commonly used for the practice of polygyny. For further explanation of G. P. Murdock's study on polygamy, see G. P. Murdock, Social Structure (New York: Macmillan Company, 1949) p. 29

${ }^{2}$ Susan BlacBurn, Women and the State in Modern Indonesia ( Cambridge: Cambridge University Press, 2004) p. 113

${ }^{3}$ For further explanation see R. Van Eck, Nasib Kaum Wanita di Bali in Peranan dan Kedudukan Wanita di Indonesia, ed. Maria Ulfah Subadio and T. O. Ihromi ( Yogyakarta: Gadjah Mada University press, 1983) p. 56 $266-275$

${ }^{4}$ For further explanation see Koentjaraningrat, Kebudayaan Jawa (Jakarta: Balai Pustaka, 1984) p.
} 


\section{B. Discourse on the practice of polygamy}

This sort of marriage is a notable problem for many societies in different circumstances. Polygamy, basically, is seen as permissible and desirable in particular circumstances such as a surplus of women after a period of war. It is alternative approach (but not an obligatory duty) to marriage under certain conditions and regulations. However, most facts show that multiple marriages often creates problems of rivalry, jealousy, hurt feelings, frustration, and inequity. Women who are in polygamous marriages may experience "double violence". This refers to the fact that wives in such circumstances not only are frequently not informed of their husband's other marriages but also experience psychological pressure, economic suffering, as well as sexual and physical violence. Accordingly, polygamy and its undesirable effects have been much debated as has been shown below:

\section{polygamy impacts toward women}

\begin{tabular}{|c|l|c|}
\hline No & \multicolumn{1}{|c|}{ Impacts } & Total number \\
\hline 1 & Financially abandoned & 37 \\
\hline 2 & Psychological pressure & 21 \\
\hline 3 & Physical violence & 7 \\
\hline 4 & Divorced & 6 \\
\hline 5 & Abandoned & 23 \\
\hline 6 & Live separately & 11 \\
\hline 7 & Terror from the second wife & 2 \\
\hline
\end{tabular}

Source: LBH APIK Jakarta ${ }^{6}$

The discourse on polygamy has been closely tied to the issue of women and equality since the $19^{\text {th }}$ century. Many scholars have written on this issue from different points of

${ }^{5}$ Leli Nurohmah, Poligami, Saatnya Melihat Realitas, Jurnal Perempuan ,edisi 30, tahun 2003

6 The data in the table were collected by LBH APIK and were analyzed by Vony Reynata of which she presented in her article entitled "Kebijakan Poligami: Kekerasan Negara Terhadap Perempuan" in JurnaL Perempuan no.31. She analyzed the three latest years data from year 2000 in Jakarta. However, her article does not reveal where exactly the research was conducted and in which community. 
view. Overall, however, the issue has been treated from a perspective emphasizing religious doctrines and cultural concepts. The following sections will review the most important and influential existing views on polygamy by examining the three main themes that have been focused on polygamy; polygamy and religious normative doctrines; polygamy and social fact; and polygamy and women issues. In addition, a discussion on the practice of polygamy will also elaborate on the incidence rates of plural marriages in Indonesia examining women general socioeconomic status in the Third World like in Indonesia and especially in rural areas.

\section{General Background of the Practice of Polygamy}

Edward Westermarck outlines various aspects of polygamy in his dissertation entitled "A Short History of Marriage". In terms of the male's side, for him, the main cause influencing men to take another wife is desire. There are various reasons for male desire according to Westermack. First, monogamy requires of a man periodical continence. In certain times, men should abstain from their wife due to their reproduction function such as pregnancy as well as the later stages of it (bearing and rearing the babies) or periodical menstruation.

Second, the beauty of young females usually attracts men. What is more, the first wives are getting older. In fact, regarding the phenomena of getting older generally women manifest the signs of age sooner than men. Third, to borrow Wastermack' phrase, that men, to some extent, have a taste for variety. In addition, he also theorized other crucial factors for men to practice polygamy. To have children from particular wives is one factor of multiple marriages. To him, this desire for offspring is certainly one of the principal causes of polygamy in the east such as in Japan. 
Furthermore, to have children is not the sole aim of practicing polygamy but also a matter of dignity. According to him, in certain societies, it is a pride to have many children and a large family and, moreover, the labor of wives such as cooking contributes to men's wealth. Interestingly, in certain circumstances, multiple wives is a testament to test men's wealth and their important social position. He also raised another important point in the emergence of polygamy. For him, the unequal distribution of wealth and economy may also lead to the practice of polygamy.

Meanwhile, another work by Tri Rahayu Widyaningrum suggests various reasons why women in certain circumstances perceive the involvement within plural marriages as an alternative solution for their problems. According to Widyaningrum, these reasons, to some extent, love, is the first but very cliché reason for a woman accepting a polygamous relationship. A woman may fall in love with a married man whether she knew or not before the man told her. Due to the dependency of these two human beings, a mutual symbiosis emerges between them to complete each other.

Material factors or money is another probable reason to get involved with the practice of polygamy. The complexity of daily need leads women to accept the offer of marriage from a married man. However, material aspects are not always arise from women themselves to be a second wife. For some parents who owe certain amounts of money to other people may ask the daughter to help them to out solve their problem by marrying whom the parents owe money to. In this situation, a woman is in the dilemma whether to prioritize herself or to save her parents. This can be considered as a simple problem but it may also complicate choice for women to decide. Moreover, if the "requirement" to be a part of polygamy practice comes from the parents is hard for children to refuse. 
Next, women generally worry in the late stages of life about having a partner or a husband particularly those who are between 20 and 45 years old. Most women experiencing this problem usually feel degraded for their "single" status. They start to question their weaknesses and to compare themselves to other women. This situation can be called a crisis of self confidence. An offering from a married man becomes an appealing. Ironically, the slogan “ only to have a partner" is a common utterance among women. In Widyaningrum's view, women facing this situation usually will make the emotional decision to marry a married man, for instance.

Interestingly, to some extent, the advantageous status of polygamy for a society (e.g. Mormon society in Utah) provides a feature in which it could enable women to develop independence and self reliance besides other considerable advantage for women. The practice of plural marriages offers a tendency for women to encourage their independence. Previously women who do not experience polygamy feel bound and limited by to their husbands. It means that polygamous marriages possibly to give freedom for the wives to do things that they never could have attempted before. They, even, can separately from their husbands. ${ }^{7}$ They must also start to rely on themselves after the break of the oneness of the family in all aspects. For instance, women and their children can run the farm and businesses on their own. Another possible consequence is that husbands and wives may have equal responsibility in financial management. However, women's independence is encouraged in a variety of ways by social condition.

${ }^{7}$ Lawrence Foster, Religion and Sexuality, The Shake, The Mormons, and The Oneida Community (Urbana and Chicago: University of Illinois Press, 1981), p. 214 "Evidently some women were grateful for the freedom from sexual demands made possible by polygamy; Mary J. Tanner noted: "It is physical blessing to weak women" 
The emphasis of sisterhood among the wives may emerge during the practice of polygamy. This practice serves an emotional function, especially when the husband is absent in the form of informal support networks and cooperation. Moreover, if the two wives already knew each other, they might be able to adjust to each other more easily. This relationship demonstrates that there is an informal female support system between these two wives especially during such crisis as those associated with economic hardship, illness, or more mundane tasks such as chores and taking care of the husband.

Unlike most other issues, polygamy has engaged women's organizations in public debate with one another and with men. Additionally, particular religious women's organizations have also been involved within the debate. Then, what exactly is at stake here in the eyes of women about the practice of polygamy is the legitimacy for the practice.

\section{Perspectives on polygamy}

\section{a. Polygamy and religious normative doctrines}

The use of religious normative doctrines plays an important role in viewing the practice of polygamy for some scholars and writers. Therefore, this section will outline two main ideas about polygamy. On the one hand, that polygamy is lawful and legitimized by the religious doctrine based on divine laws. On the other hand, that polygamy cannot easily to be practiced and, to some extent, it may be seen as an unlawful practice.

In Islam, polygamy enters the stage of religious discussion due to the different interpretations and understandings of the normative doctrine by Muslims themselves. Polygamy, basically, is regarded as a lawful practice for Muslims since there is a 
theological basis in the Quran. ${ }^{8}$ However, some Muslim scholars argue that polygamy cannot easily be practiced by Muslims. Quraish Shihab, for example, states that the verse discussing polygamy in the Quran does not specifically allow or prohibit the practice. This verse only presents the phenomena of polygamy to Moslems in a general way. For this scholar, the practice of polygamy can only be practiced by adhering to strict requirements. Similarly, another scholar, Muhammad Abduh, also points out that polygamy is very difficult to be practiced lawfully, since many Muslims cannot fulfill the requirements. In addition, Mulia argued that the practice is basically decreasing women's dignity although it is possible that there are certain women who accept polygamy. ${ }^{9}$ All the arguments canvassed above, polygamy basically may come to the level of lawfulness as the requirements of the practice already stated in the Qur'an itself. However, it may come also to the level of unlawfulness whenever the practitioners go beyond the requirements. Therefore, the debate on theological base of the practice of polygamy should be considered also the condition of the practitioners (husband and wife) since the verse textually stated it's legitimacy to be practiced.

\footnotetext{
${ }^{8}$ The theological base that is usually used by Muslim s for polygamy is Qur'an (4:3). This chapter consisting of 167 verses. This surah is named by An-nisa due to mostly the explanation is about women. Verse 3 of this surah is textually interpreted to be the legitimacy of the practice of polygamy. However, this theological base is still in debate among Muslims. Different interpretations are implemented on this verse The verse was translated and interpreted by Muhammad Baqir Behbudi, in " The Qur'an, A New Interpretation” (Great Britain: Colia Turner Curzon, 1997)......"It is true that you are entitled to marry the female orphans in your care and place their dowries, along with their inheritances, in your safe keeping. It is also true that you may may use their property, provided you secure it, to finance your commercial enterprises. Whatever use to make of the property of orphans in your care, make sure that their rights are safeguarded at all times. If you fear that their rights will be in danger, do not marry the orphans in your care; instead, marry women who have come of age and who are able to hand over their property to you freely, thus making it lawful. Take two, three or four women as your wives-provided that you you are able to treat them all with perfect equality"...... M. Quraish Shihab, Tafsir Al-Misbah, Pesan, Kesan dan Keserasian Al-Qur'an (Jakarta: Lentera Hati, 2000, vol. 2) p.313-314 emphasized the permission of taking multiple wives on the substantial matter of the order itself. In this verse, according to him, men are allowed to take another wive in relation to the independence of slavery. Therefore, he focused on the part "if it is necessary, you may take simultaneously....". So, it is not " you should take simultaneously......". The two scholars emphasized the protection of the orphans, while polygamy is not sole order or obligation for men to practice regarding the requirements.

${ }^{9}$ Musdah Mulia, Pandangan Islam Tentang Poligami (Jakarta: LKAJ, 1999) p.50-51
} 
In the course of the debate on the incident of polygamy and its legal status, a work proposed by Nurbowo and Joko's on "Indahnya Poligami” demonstrates the positive sides of polygamous marriage and the reasons it is practiced based on normative doctrines. In this work, they emphasize the fact that polygamy can prevent Muslim's from unlawful things such as prostitution as well as to show that this practice is not devoted only for religious leaders or rich men, but also for pious Muslims. ${ }^{10}$ Ajjahrani in his book “ Poligami Dari Berbagai Persepsi” outlined three main points of polygamy issue. First, in his view, Islam allows the practice to be accepted without doubt for its desirable effect. ${ }^{11}$ Second, Islam reveals the rule of polygamy for Moslems to be accepted but it does not mean that they have to practice this sort of marriage. ${ }^{12}$ Third, The aim of the issuing the case of polygamy is to protect women's dignity as they were previously abandoned for unlimited practice of polygamy, requirements as well as unlimited number of wives. ${ }^{13}$ In this level of discussion, it may be safely argued that the theological base of polygamy should be considered as the alternative solution of particular women's condition which is very phenomenological and contextual. It can be concluded also that the normative doctrines of Islam do not order explicitly to practice polygamy but to give a probable solution for particular cases in society in relation with women.

Echoing the concerns of proponents for the more desirable aspects of plural marriage, other doctrinal based works on the issue of polygamy suggest different ideas. Mulia

\footnotetext{
10 Nurbowo and Joko. M. Apiko, Indahnya Poligami Pengalaman Keluarga Sakinah Puspo Wardoyo ( Jakarta: Senayan Abadi Publishing, 2003) p. 5

11 Musfir Aj-Jahrani, Poligami dari Berbagai Perspektif (Jakarta: Gema Insani Press, 1996) p. 39 and 81. For further discussion, See Nuruddin Itar, Madza an il Mar'ah, p. 144-145

${ }^{12}$ Aj -Jahrani, Poligami......., p.39 and 81. See Mustafa As-Siba'i , Al-Mar'ah Bayna al-Fiqh wa alQonūn,p. 97-98 Juz 1 p. 333

3 Aj- Jahrani, Poligami........ p. 38 and 81.See Sūnan Tirmidzi, juz 3, p. 304 and Sūnan Abi Daud.
} 
suggests that the use of normative doctrines must be carefully understood and practiced. ${ }^{14}$

She emphasizes that the doctrine does not order Muslims to practice polygamy since the doctrine is related to the care of orphan's, not to taking many wives. Moreover, women involved in the practice of polygamy mostly become the victims of unfair treatment. Furthermore, she suggests that there might be a distortion of the practice of polygamy in society. In general, people in society base their reason to practice plural marriage on following what the prophet Muhammad did the so-called Sunnah. ${ }^{15}$

According to this scholar, people usually relate the practice of the Prophet's sunnah to the practice of polygamy. If it is so, it means that there is a reduction of the meaning of the sunnah itself. In fact, sunnah itself brings the message of justice and peace in social life. The irony is that, people practicing plural marriage tend to forget and ignore those messages. So to speak, it can be said to be the implementation of sunnah but in reality it breaks it. A substantial part of her argument is that the practice of polygamy in society generates more problems. For instance, many marriages are not registered formally (nikah sirri) to KUA, violence towards women in the family, the loss of responsibility of husbands for the wives and the children economically as well as morally. All these impacts can be a result of the practice of polygamy. Finally, taking many wives in one marriage generates more negative impacts rather than the positive ones.

${ }^{14}$ Mulia, Pandangan Islam........, p. 27 and p.34-35

${ }^{15}$ Sunnah, for Musdah herself is defined as all the actions in forms of spoken or behavior of the Prophet which cover all the aspect of his life and other prophet. However, basically other most classical theories of sunnah was usually incorporated three essential elements. In classical manuals of Islamic law, the term sunnah refers to the authoritative example set by Muhammad and recorded in tradition (hadith; akhbar) about his words, his actions, his acquiescence to the words or actions of others, and his personal characteristics (sifat). See.....Daniel. W. Brown, Rethinking Tradition, ( Cambridge: Cambridge University press, 1996) p. 6 . For muhaddithuns in the classical book Sunnah is defined as those which are referred to the Prophet including His sayings, actions, attributes as well as His silence.. for further discussion on Sunnah from different perspectives see Muhammad Ibn 'alwĩ al- Malikĩ al- Hasanĩ, usul al-Hadith al-Syarifĩ ( Jeddah: Mathba'I sahr, 1986) p. 1-3 
Arguments against polygamy are also presented by Fayumi, et. al.'s work in which she asserted that the Islamic principle of marriage is based on monogamy. ${ }^{16}$ It is not Islam that advocates polygamy but it is Islam responding to previous marriage practices. Therefore, the doctrine must be interpreted very carefully since it also provides strict requirements to practice polygamy. Then, two articles written by Noryamin Aini and Faqihuddin Abdul Qodir propose similar ideas that polygamy is a cultural matter and the doctrines arose to give the solution not merely to legitimize the practice. $^{17}$

The resistance to changing the understanding of the doctrinal bases for the legitimacy of polygamy is responded by other Muslims groups of which they base their argument on the doctrines themselves. As discussed earlier that there is a tendency of aforementioned works to issue the "unlawfulness" of polygamy, it generates a reaction stating that there are no doctrines whether in the Qur'an or hadith which legally prohibit polygamy. The source of these two different arguments on the practice of taking many wives is basically taken from one verse in the Qur'an (4: 3). For those who passionately opposed polygamy, this verse states clearly that basic foundation of marriage is monogamy. As a result, if it is practiced in polygamous form, the marriage cannot be considered as legal. This sort of option is called by this opposing group as the renewal of Islamic laws. Furthermore, the issue has been documented by gender mainstreaming division of Department of Religious Affairs in a book of Islamic laws. Above all, the issue of the legality of polygamy based on Islamic doctrines is still stirring a debate in the level of interpretation.

\footnotetext{
${ }^{16}$ Badriyah Fayumi, ET. al., Issu-Issu Gender Dalam Islam (Jakarta: pusat studi wanita IAIN, 2003) p. 41 and 47

${ }^{17}$ Noryamin Aini, Poligami Sebuah Dilema Moral, paper presented on 23 April 2004 in Forum Ijtihad Jama'iy. Faqihuddin Abdul Qodir, Fenomena Poligami (Perspektif Fiqih Paper), Presented in Public discussion on 8 September 2003. Both are unpublished articles. See also the case of Naufalbin Mu'āwiyah in Ibn Mājah, Sunan Ibn Mājah, Kitāb an- Nikāh, hadith no. 1942. Muwaffaq ad-Dĩn Abĩ Muhammad 'abdillah bin Qudāmah, almughnĩ wa asy-Syarh el-Kabĩr, first edition (Beirut: Dār al- Fikr, 1404/1984) p. 436
} 


\section{b. Polygamy as a social fact}

This section examines different types of polygamy as a social fact in different societies. These works suggest that polygamy in certain social life as well as certain societies is regarded as an acceptable form of marriage. A study in Thailand, for instance, suggests that human beings, historically, had practiced polygamy, since ancient times for various purposes. The case in Thailand shows that "there are occasionally additional wives, though this is not legally sanctioned". A young girl, of a less wealthy family might accept a second wife position to make her future secured. ${ }^{18}$ This is closely linked to Al-Hatimi's work stating that some eastern societies regard polygamy as the best form of marriage. According to him, polygamy is mostly practiced by people who have a high status in society and who are rich, but the reason for doing that is only economic. ${ }^{19}$

In certain societies, polygamy also occurs not only for economic reasons but also for social reasons. For example, Chaudry's work shows that:

Polygamy has its roots in the social and economics demands of African societies. More wives mean a more bountiful harvest. And the surplus wealth from the harvest is "invested" in additional wives since rich and poor live much alike, a man's success is judged by the number of wives. The wives share the benefits of his prestige and enjoy the security of his household., 20

In addition, a work by Murthadha Muthahhari proposes two historical notes on polygamy in Iran in the age of Sassanian. These two notes revealed that the family system in

\footnotetext{
${ }^{18}$ Whyte, the Women... ,.p. 76. He quoted Hanks research which was conducted in 1963 about the practice of polygamy in particular Asian society

${ }^{19}$ Said Abdullah Al-Hatimi, Citra Sebuah Identitas Wanita Dalam Perjalanan Kesejarahan, trans. by Adi.Khalid,( Jakarta: Amar Press, 1988) p. 58

60. Whyte "The Women ..........., p. 76
} 
Sassanian Iran commonly involved polygamy in which men might marry more than one woman. $^{21}$

In Indonesian history, the practitioners of polygamy were mostly come from the high status classes. Research by Koentjaraningrat showed that after World War II, polygamy commonly occurred in rich families among Kauman social santri groups. Based on their religious beliefs, they practiced polygamy but never took more than four wives. Sometimes they lived together in one house following a "priyayi" life style. However, those who are santri, having more than one wife, usually built separate houses for their wives. ${ }^{22}$ In line with Koentjaraningrat observation, a study was conducted by Leila Ahmed on women's life in the Mediterranean Middle East. Her study revealed two main descriptions of women's condition in this age. First, the marriage age for girls ranged between twelve to seventeen at most sometimes even younger. Second, polygamy was another phenomenon in certain social structures such as in the ruling classes. ${ }^{23}$. So to speak, polygamy was a norm in these classes where the number of wives was considered as the expression of men's power and class.

Recent research by Barry Levy on polygamy in contemporary Indonesian society revealed that most of the people that he interviewed were positive about their involvement with polygamy. This research looked at the population of urban and rural areas in several areas in Indonesia. The study included areas in Central Java, Lombok, Makassar,

${ }^{21}$ Arthur Christensen, an Iranolog, wrote that the marriage system in Iran in the age of Sassanian was polygamy. However, in the case of the number of wife was based on the capability of the husband. Then, Sa'id Nafisi in his "Tarikh - e Ijtima'i Iran az inqirad-e Sassanian ta in inqirad ta enqirad-e umawiyah wrote that men might take unlimited number of wive, see Murtadha Muthahhari, Hak-Hak Wanita Dalam Islam. Trans. Edition (Jakarta: PT Lentera Hati, 2004) p. 211-212

${ }^{22}$ Radjab, Meninjau Polygamy..........., , p.72. For further explanation, see Koentjraningrat, Kebudayaan Jawa (Jakarta: Balai Pustaka, 1984) p. 266- 275

${ }^{23}$ Leila Ahmed, Women and Gender in Islam, Historical roots of Modern Debate (Michigan: Bookcrafters, Inc, 1992) p. 103-104 
Jogjakarta, and several other areas. He also interviewed a range of individuals with firsthand experience in or with multi wife families. Accordingly, this work shows that at least some families in certain societies in several areas in Indonesia accept polygamy and live in a comfortable situation within multiple wife marriages. ${ }^{24}$

To sum up, the practice of polygamy has been internalized into human beings' life socially for different reasons and spectrums. On the one hand, this sort of marriage is accepted due to the social or economic situations which allow polygamy as the solution. Further, the practice of polygamy may be a part of social system of marriage in certain societies. On the other hand, it probably cannot be accepted or merely practiced for certain reasons by particular individuals.

\section{c. Polygamy and women issues}

This section investigates the general description of the impacts of polygamy toward women which tend to be more undesirable. The supporting argument of the idea is that some factors such as social systems (patriarchy system) and the implementation of legal system make polygamy exist in certain societies. Another point is that polygamy generates violence towards women will also be outlined in this section.

Firts, Karim in his examination of polygamy in Islam maintains that polygamy had been also practiced in Arabic society long before Islam came in which the number of wives was unlimited. He stated that it was part because of the patriarchal systems that society held together. Furthermore, he described the ancient Arabic family composition consisting of a

\footnotetext{
${ }^{24}$ Barry Levy conducted the research for McGill project in Canada aiming to have comparative view about polygamy in Islam and Judaism.
} 
man as the key person and some free women including women slaves (milk al yamin). In this kind of family the women used the term of "ba'al" for the husband. ${ }^{25}$

Second, in terms of the law, women's rights are usually ignored. For instance, Labib's study on marriage laws in Indonesia suggests that women basically must be included and considered as a part of consideration of polygamy. ${ }^{26}$ The study reveals the implication of the laws and the impacts on women. In Indonesia, since 1974, marriage had been regulated formally by Law No 1 , implemented on $1^{\text {st }}$ October 1975 . Polygamy was regulated by these laws and also by Compilation of Islamic Laws (Kompilasi Hukum Islam). ${ }^{27}$ In these marriage laws, it is stated clearly that the basic principle of marriage is monogamy and, even though there is a possibility to practice polygamy, it is limited only to four wives. ${ }^{28}$ If a husband wants a polygamous marriage, he must pass through certain procedures. He must submit a proposal to the court. The court will conduct an investigation whether he fulfills the requirements or not by asking the testimony of his wife. A husband may be fined $(7,500$ rupiahs) if he breaks the laws. ${ }^{29}$ However, the fact shows the reality that women are still in weak position although marriage laws regulate polygamy procedures.

25 Khalil Abdul Karim, Historisitas Syariat Islam, ed. Trans. M. Faisol Fatawi,( Yogyakarta: P.T. Pustaka Alief, 2003) p. 45

${ }^{26}$ Labib MZ, Rahasia Poligami Rasulullah SAW.,(Jakarta:CV. Bintang Pelajar, 1986) P. 28

${ }^{27}$ Compilation of Islamic chapter 55 Laws verse 1 states that "to marry more than one wife in the same time is only limited to four wives". Then, in chapter 56 verse 3 , it states that " a marriage with second, third or fourth wife without the permission from Religious Court has no law legitimacy".

${ }^{28}$ UU no 1 year 1974 chapter 3verse 1-2 and . See Khoiruddin Nasution, 2002, Status Wanita Di Asia Tenggara, Study Terhaadap Perundang-undangan Perkawinan Kontemporer Di Indonesia Dan Malaysia (Jakarta,:Inis Leiden, 2002) p. 107-111. As the comparison, other Islamic countries such as Tunisia, Turki and Irak prohibit the practice of polygamy. Tunisia banned polygamy altogether and offered one year imprisonment and fined the doer of 200,000 Frank upon the violators. See Mohamad Atho Mudzhar, Islam and Islamic Lawin Indonesia (Jakarta: Ofiice of Religious Reseearch and Development, and Training of Ministry of Religious Affairs Republic of Indonesia, 2003) p. 97

${ }_{29}^{29}$ P. no.9 year 1975 chapter 40 , 42, 43 and 45 verse (a), Khoiruddin, Status Wanita........, p.110. 
Third, LBH APIK Jakarta conducted a study on the impact of polygamy on women and children. ${ }^{30}$ The result of the study shows that polygamy generates certain undesirable impacts mostly on women such as economic and physical as well as psychological violence. These results had a similar conclusion with a polling conducted by Yayasan Jurnal Perempuan that revealed that women often become victims in polygamous marriage. This sort of marriage only privileges men. Conversely, women receive most negative impacts from the practice of polygamy. ${ }^{31}$

\section{Polygamy in Indonesia between concept and Realities}

\section{a. Polygamy as a legal practice of marriage}

In the Indonesian context, polygamy has a much older history of being permitted according to a number of different and local customary legal systems so-called adat. In addition, polygamy has been legal since the marital law of 1974 already strictly regulated the marriage involving more than one wife simultaneously. They state that those who want to marry for the second time, with a second wife, must defer to certain requirements. Unfortunately, this regulation has only been implemented successfully for civil servants and not for the general public. Therefore, the case of unregistered marriage is something that commonly makes women experience undesirable conditions during marriage. This is especially true for second wives, who are persecuted by first wives who feel that an outsider has destroyed their families.

\footnotetext{
${ }^{30} \mathrm{LBH}$ APIK is one NGO in Jakarta concerned with advocacy for women and gender issues from legal formal law aspect.

${ }^{31}$ The polling was conducted during 15-20 september 2003 and involved 100 women in Jakarta randomly from different backgrounds, see Yayasan Jurnal Perempuan, 2003, vol. 31 p.100-101.
} 
Another factor that supports the existence of polygamy in Indonesia is the norms held by certain sub-groups. In some parts of Indonesian society, polygamy is regarded as a" formal" system of marriage similar to some traditional Irian tribes. ${ }^{32}$ For instance, women's acceptance of polygamy is not only, in certain cases, legitimized by social structure, politics and economics but also due to a Indonesian cultural worldview which is dominated by a patriarchy system. Furthermore, she pointed out that polygamy cases are not only the result of religious doctrines but also gender issues since it includes issues related to how men perceive women. If women are perceived as weak, then they should be economically, socially and politically protected. In addition, Radjab discussed polygamy phenomenon in Javanese "priyayi" community ${ }^{33}$ in his historical record. According to him, the practice of polygamy in this community began long before the introduction of Islam. Otherwise, this kind of marriage already existed in certain parts of Indonesia.

Interestingly, group of Muslims, particularly for Moslems living in Indonesia propose a different point of view on the practice of plural marriages. For instance, the benefits of the practice of polygamy have been suggested by Madurese Islamic organizations in 1930s. For these groups, polygamy protects women (especially young women) from sexual abuse. This practice is also as an alternative way to have children when women are incapable of having children. Moreover, marriage is seen as a divine law, and polygamy is regarded as a response to particular circumstances. ${ }^{34}$

The incidence of polygamy is, to some extent, perceived as a part of the human reality. A reality that situates this practice as emergency response which cannot be avoided.

32 Farida, Polygamy: Dilema bagi Perempuan, Jurnal perempuan (Jakarta: Yayasan Jurnal Perempuan, 2002) p. 75

${ }^{33}$ In Javanese society people are usually compartmentalized socially by two different structure. On the one hand, Those who are coming from noble family are categorized as Priyayi group and ordinary people as the second group, on the other. See Radjab, Meninjau Poligami........, p. 71

${ }^{34}$ jurnal perempuan, Debat seputar Polygamy, Vol. 19. p.81-84 
Nuruddin in his work "Ada Apa dengan Wanita?" suggests that men should take many wives in their marriages due to certain factors. ${ }^{35}$ First, the reality of life shows that there is law of the nature namely mortality and birth. According to him, the mortality degree for men is higher than that for women. Therefore, the proportion of women is far greater than men although men's birth rate sometimes is higher than women's. Next, There is a reality in social life that men are forced to experience heavy burden such as war or to work in factories. This situation put men's position in a more dangerous situation compared to women in terms of their mortality.

Third, unpredictable condition of the first wife is one possible factor for men to take another woman when conditions do not support the main goal of marriage. This sort of argument seems to be a "wise" legitimacy for polygamy. For Nuruddin, polygamy is the solution rather than to divorce the first wife as the husband still loves her. Moreover, in his view, to divorce a wife is undesirable and inhumane.

Furthermore, Nuruddin questions the argument stating that the practice of polygamy must be abolished in Islamic laws (syariah). For him, the opponents of plural marriage always base their reaction on the concept " fairness" among the wives of which they try to show that people do not have the capability to be fair to all the wives in polygamous marriage. ${ }^{36}$ Therefore, there is no Islamic law regulating the practice since no one can be fair. As a counter argument, Nuruddin pointed out that his opponents are playing with the Qur'an itself. In fact, the concept of " fairness" in this verse is not "fair" in terms of all human aspects such as emotion, love or affection. This is the case for what human beings

\footnotetext{
${ }^{35}$ DR. Nuruddin Itr, Ada Apa dengan Wanita (translated edition from Madza 'anil al Mar'ah), translated by Pahrudin HM, (Yogyakarta: TASLIMA -PRISMA MEDIA, 2004) p. 188-189

${ }^{36}$ See....Quran, Ian-Nisa: 129
} 
are possible to do based on the level of their position as human beings. It can be understood as the way to make the two wives (or more) are equally treated as well as provided for.

In his final conclusion, he strongly emphasized that the practice of polygamy which is regulated by Islamic laws is allowed $(m u b a h) .{ }^{37}$ Therefore, there is no authoritative position to change the law. The primary consideration of this argument is that to avoid immoral outrage of illegal relationship between men and women when polygamy is strictly prohibited. In conclusion, in his view, all the arguments relating to the reality of life regulate or allow polygamy formally as well as religiously. To sum up, this kind of argument on legality of polygamy is not merely the positive aspects of the practice itself and the need of the practice but it is a choice to have better condition in particular circumstances.

\section{b. Women and public actions toward polygamy}

The arguments made on both sides of the debate over polygamy are complex and change over time. Basically, in the Indonesian historical context, serious debates surrounding the issue of polygamy began in the middle of the 1920s when women began to refuse marriages involving multiple female partners, both individually as well as organizationally. Opposition to polygamy has driven Indonesian women to public action on many occasions. For instance, in 1950, female factions in Indonesian parliament recommended the outlining of general regulations for marriage of all Indonesian citizens where polygamy must be restricted under strict rules. Furthermore, in 1955 there were protests against President Soekarno' polygamous marriage and in 1958, one member of

\footnotetext{
${ }^{37}$ The term mubah refers to one of the five basic standards of Islamic law. Mubah means can be practiced but there is neither reward from the God or punishment.
} 
female parliament demanded that monogamy rules must be implemented for all Indonesian citizens.

Basically the campaigns for a marital law had started from 1940s to the 1970s. What is more, as the Jakarta Post revealed that there were also demonstrations against plural marriage practice. ${ }^{38}$ Consequently, although it took several years, polygamy became formally regulated in the marital law of 1974. The laws stated that those who want to marry for the second time, with a second wife, must meet certain conditions and requirements. Unfortunately, this regulation was only implemented successfully for civil servants not for all citizens. Therefore, the case of unregistered marriage remained common in Indonesian society that made women; either the first or the second wife and experience undesirable conditions during marriage. Otherwise, the formalization of polygamy in legal regulations and public policies has been continuing up to present.

\section{The Impacts of Polygamy for Women}

\section{a. Economic Impact of polygamy for women}

For many, the argument that husbands are obliged to support his family is the center of the debate about the economic aspect of the family. Women worry in this practice that their husbands are incapability of supporting the family economically. Ideally, husbands must advocate for their wives rights in forms of being able to earn their living or from marital insecurity. This is the case in the patrilineal system of social life, more specifically in Muslim communities. One of the Islamic conception about the husbands roles in marriage is that husband is foremost responsible of the economic support for the wife and the children. Then, in a polygamous marriage, husbands may face a double burden

\footnotetext{
${ }^{38}$ Jakarta post 30 July 2003.....see Blackburn, Women and the State........, p. 112
} 
economically especially for those who are less wealthy like in Indonesia where most of citizens living in less wealthy condition. In doing so, to quote Susan BlackBurn " how then was a polygamous husband going to support more wives and their children in a satisfactory manner? "39.

In this circumstance, women must try to build their own independence since the family income must be shared with the younger women who may not contribute to the family. Moreover, the economic problem is significant for women in the countryside in which agriculture is their major area of employment. This discussion must be put in the context of Indonesia as a developing country. In countryside areas, usually women's primary contribution is to family farming. Therefore, women in this area are commonly weak economically. However, polygamy practice forces them to find other means to be more independent economically. This undesirable impact resulting from polygamy practice is, perhaps, the most threatening outcome of polygamy practice for most women.

\section{b. Social Impact of polygamy for women}

Another concern of women towards polygamy is its social consequences. This is about family stability when it must be divided into many sub families. By contrast, women sometimes choose whether to accept or to refuse the practice. To refuse polygamous marriage results in a new status for a wife as a "divorced woman" with its social consequences. Meanwhile, when women decide to accept their husbands to many wives, these women must also face other consequences. For instance, it is a common to point to the deleterious effects on society of divided families where children of different wives and

\footnotetext{
${ }^{39}$ Blackburn, Women and The State....p. 116
} 
their mothers compete and fight over their share of their father's resources. ${ }^{40}$ Ironically, women in general possess little knowledge about their rights as wives particularly about the economic aspects of marriage.

The wider social context of marriage more specifically about the age of women in marriage is sometimes ignored. Moreover, only few women know their rights in marriage as well as in divorce and their statuses in society outside of marriage. Basically, for Indonesian women, social outcomes of polygamy are less desirable. Therefore, there is an idea that one way to protect women from getting involved within plural marriage is to prevent them from being forced into early marriage. There must be a legal minimum age for marriage. There is also a need to give women better access to divorce or to allow them to escape from polygamous unions. The primary emphasis of this social outcomes discussion is that to create an equal position between men and women regarding the impact of polygamy practice.

\section{Conclusion}

As has been shown, women and the practice of polygamy can be discussed in quite varied ways. There are always two different arguments and various explanations for plural marriages whether from men or women. This practice of marriage insists on the emotional sacrifies either from men or women to prevent the undesirable impacts generating from the practice. Regardless its legality, a primary demand on monogamous marriage is still the first priority for women. Overall, polygamy has been a notable issue in Indonesia and elsewhere in the world and remains a threat for particular groups that must be put on a wise perspective and careful practice for the sake of humanity.

\footnotetext{
${ }^{40}$ Blackburn, Women and The State...p. 118-119
} 


\section{BIBLIOGRAPHY}

.Abdulqodir, Faqihuddin, Fenomena poligami; Perspektif Fiqih Perempuan (unpublished paper), presented on $8^{\text {th }}$ September in Jogjakarta in public discussion, 2003.

Abdurrahman As-Sanan, Arij, Memahami Keadilan Poligami (trans. By Ahmad Sahai Hasan, Lc), Jakarta: PT Global Media Cipta Publishing, 2003.

Ahmed, Leila, Women and Gender in Islam, Historical Roots of Modern Debate. Michigan: Bookcrafters, Inc, 1992.

Aini, Noryamin, 2003, Poligami Sebuah Dilema Moral (unpublished paper), Presented in on 23 April 2003 at Forum Ijtihad Jama'iy.

Aj-Jahrani, Musfir, Poligami dari Berbagai Perspektif. Jakarta: Gema Insani Press, 1996.

Al-Hatimi, Said Abdullah, 1988, Citra Sebuah Identitas Wanita Dalam Perjalanan Kesejarahan. trans. by Adi. Khalid. Jakarta: Amar Press, 1998.

Ali Ash-Shabuni, Syekh Muhammad, Persepsi-Persepsi dusta Dan Batil Tentang Kasus Poligami Rasulullah SAW. Jakarta: PT Bulan Bintang, 1988.

Jakarta: Risalah Gusti, 1991.

BlackBurn, Susan, Women and the State in Modern Indonesia. Cambridge: Cambridge University Press, 2004.United Kingdom.

Brown, Daniel. W., 1999, Rethinking Tradition in Modern Islamic Thoughtt. Cambridge: Cambridge University Press, 1999.

Elington, Stephen and M. Christian Green, Religion and Sexuality in Cross-Cultural Perspective. New York: Routhledge, 2002.

Farida, 2002, Polygamy: Dilema bagi perempuan, Jurnal perempuan, 31, 2000.

Fayumi, Badriyah, at. al, Isu-Isu Gender Dalam Islam. Jakarta: Pusat Studi Wanita Insitut Agama Islam Negeri Jakarta, 2003.

Foster, Lawrence, Religion and Sexuality, the Shake, the Mormons, and the Oneida Community. Chicago: University of Illinois Press, 1981.

Hasyim, Syafiq, Hal-hal yang Tak Terpikirkan Tentang Isu-isu Keperempuanan dalam Islam. Bandung: Mizan, 2001.

Karim, Khalil Abdul, Historisitas Syariat Islam, ed. Trans. M. Faisol Fatawi,. Jogjakarta: P.T. Pustaka Alief, 2003. 
Labib, MZ, Rahasia Poligami Rasulullah SAW.. Jakarta: CV. Bintang Pelajar, 1986.

Levy, Barry, Polygamy In Judaism and Islam (an interim report, Canada), $2001 .$.

Mayling Oey, et al., Indonesian Women, The Journey Continues. Canberra: Goanna Print Pby Ltd., 2000.

Mulia, Siti Musdah, Pandangan Islam Tentang Poligami. Jakarta: LKAJ, 1999.

-------------, Islam Menggugat Poligami. Jakarta: PT Gramedia Pustaka Utama, 2004.

Muthahhari, Murtadha, Hak-Hak Wanita dalam Islam.translated by M. Hasyem. Jakarta: Lentera, 2002.

Nasution, Khoiruddin, Status Wanita Di Asia Tenggara: Studi Terhadap Perundang-undangan Perkawinan Muslim Di Indonesia dan Malaysia, Jakarta, INIS, Leiden, 2002.

Nurbowo and Joko. M. Apiko, Indahnya Poligami Pegalaman Keluarga Sakinah Puspo Wardoyo. Jakarta: Senayan Abadi Publishing, 2003.

Nurrohmah, Lely, "Poligamy: Saatnya Membaca Realita.”, Jurnal Perempuan 31, 2003.

Nuruddin Itr., Ada Apa dengan Wanita (trans. edition from Madza 'anil al Mar'ah), translated by Pahrudin. Jogjakarta: HM, Taslima - prisma media, 2004.

Orr, Robert Whyte and Pauline Whyte, the Women in Rural Asia. USA: Westview Press, Inc., 1982.

Radjab, Budi, Meninjau Polygamy; Perspektive Anthropology dan keharusan Mengubahnya , Jurnal Perempuan. Jakarta: Yayasan jurnal perempuan, 31, 2003.

Rahayu, Iin Try Perempuan dalam Bayangan, Jogjakarta: Saujana, 2004. 